\title{
Analisis Efektifitas Pembelajaran Daring di Sekolah Dasar Pada Masa Pandemi Covid-19
}

\author{
Melia Astuti \\ Universitas Negeri Semarang \\ *Penulis korespondensi: astutimelia@students.unnes.ac.id \\ DOI : https://doi.org/10.21580/jieed.v1i1.7224 \\ Received: 2020-12-30, Revised: 2021-03-27, \\ Accepted: 2021-03-27, Published: 2021-03-28
}

\begin{abstract}
Abstrak
Penelitian ini bertujuan untuk mengetahui dampak pelaksanaan pembelajaran daring terhadap pengajar dan kualitas pembelajaran. Metode penelitian ini adalah survei dengan instrument angket likert. Hasil penelitian ini menunjukan bahwa tingkat keefektifan pembelajaran daring dimasa pandemi Covid-19 adalah 39,6\%, artinya berada pada ketegori rendah. Beberapa kendala yang ditemukan dalam pelaksanaan pembelajaran daring di masa pendemi Covid-19 adalah: pengajar kesulitan membangun komunikasi dua arah dengan siswa, terjadi miss komunikasi baik antara siswa dengan pengajar, maupun wali siswa dengan pengajar, perangkat pendukung pembelajaran daring kurang memadai, koneksi internet kurang baik, dan motivasi belajar siswa dalam mengikuti pembelajaran menurun.
\end{abstract}

Kata Kunci: pembelajaran daring di Sekolah Dasar, pembelajaran selama Covid-19, efektifitas pembelajaran daring

\section{Analysis of The Effectiveness of Online Learning At Elementary Schools During Pandemic Covid-19}

\begin{abstract}
This study aims to determine the impact of the implementation of online learning on teachers and the quality of learning. This research method is a survey with a Likert questionnaire instrument. The results of this study indicate that the level of effectiveness of online learning during the Covid-19 pandemic was 39.6\%, which is in the low category. Some of the obstacles found in the implementation of online learning during the Covid-19 epidemic were: teachers had difficulty building two-way communication with students, there was a miss of communication between students and teachers, as well as student guardians and teachers, inadequate online learning
\end{abstract}


support devices, insufficient internet connection good, and students' motivation to participate in learning decreased.

Keywords: online learning at elementary school, learning during Covid-19, efektifitas pembelajaran daring

\section{PENDAHULUAN}

Salah satu dampak yang paling dirasakan dari adanya pandemi Covid-19 di dalam dunia pendidikan adalah diberlakukannya sekolah daring atau full online. Pada jenjang perkuliahan atau SMA sistem sekolah daring bisa berjalan dengan baik karena siswa pada tingkat ini sudah paham akan pentingnya sekolah dan tetap mengikuti pembelajaran meskipun diberlakukan secara daring penuh. Namun hal berbeda terjadi pada jenjang pendidikan SD, hal ini dikarenakan tidak dapat dipungkiri bahwa pelaksanaan sekolah daring khususnya pada jenjang Sekolah Dasar sangat diperlukan bantuan pengawasan dari banyak pihak baik pengajar maupun orang tua siswa.

Namun seperti yang dijelaskan oleh Wiyanto (2020) terjadinya pengalihan proses pembelajaran yang dilakukan secara tiba-tiba dikarenakan adanya pandemic Covid-19 juga membuat pendidik, siswa, maupun orang tua menjadi kaget, perubahan ini mengharuskan semua elemen pendidikan harus sigap merespon dengan sikap dan tindakan suapaya mau mempelajari hal-hal baru.

Selain itu diperkirakan terdapat beberapa dampak lain yang dirasakan oleh siswa maupun pengajar di Sekolah Dasar. Di sisi lain dikarenakan sistem pembelajaran Sekolah Daring ini masih tergolong sebentar di implementasikan di Sekolah-sekolah dasar, dikhawatirkan juga dengan segala hal baru yang harus dipelajari baik oleh tenaga pengajar maupun oleh siswa dalam waktu yang relative sangat singkat dikarenakan adanya sekolah daring ini, akan mengurangi atau mempengaruhi efektifitas pembelajaran siswa maka keefektifan dari pembelajaran daring inipun masih sedikit diragukan jika dibandingkan dengan proses pembelajaran memgunakan metode tatap muka.

Penelitian terkait dampak dan efektifitas pembelajaran daring yang pernah dilakukan sebelumnya beberapa diantaranya adalah: penelitian yang dilakukan oleh Riskey Oktavian (2020) yang berjudul "Efektivitas Pembelajaran Daring Terintegrasi Di Era Pendidikan 4.0" jurnal ini membahas tentang efektifitas pembelajaran daring dan juga pembandingan efektifitas pembelajran daring jika dibandingkan dngan pembelajaran konfensional. Selain itu juga ada penelitian yang dilakukan oleh Siti Sri Wulandari pada tahun 2020 yang berjudul: "Pembelajaran Daring Sebagai Upaya Study From Home (SFH) Selama Pandemi Covid 19" Permasalahan yang dibahas dalam jurnal ini adalah mengidentifikasi kegiatan pembelajaran daring di rumah-rumah siswa sebagai upaya mendukung yaitu belajar dari rumah selama pandemi covid 19 . 
Hasil yang didapatkan dalam penelitian ini adalah Pembelajaran daring adalah salah satu solusi untuk menerapkan social distancing guna meminimalisir penyebaran virus Covid-19. Hal ini dikarenakan pembelajaran daring dilakukan secara online dengan jarak yang jauh. Sehingga bisa menghindari kerumunan yang meruppakan salah satu penerapan social distencing. Selian itu penelitian sebelumnya yang juga membahas tentang efektifitas pembelajaran daring adalah penelitian dari Asep Priatna pada tahun 2020 yang mengambil judul: "Efektifitas Implementasi Pembelajaran Daring (Full Online) Dimasa Pandemi Covid- 19 Pada Jenjang Sekolah Dasar Di Kabupaten Subang".

Hasil penelitian ini menunjukan bahwa berdasarkan delapan indikator yang diteliti, yaitu: 1) Kenyamanan Pembelajaran MasaPandemi; 2) Kemampuan Literasi Digital Guru; 3) Tingkat Adaptasi Siswa terhadap Pembelajaran; 4) Kecukupan Perangkat; 5) Koneksi Internet; 6) Biaya Pembelajaran Daring; 7) Tingkat Kenyamanan Aplikasi; dan 8) Komitmen Daring Pasca Pandemi, dapat ditarik kesimpulan tingkat efektifitas pembelajaran adalah sekitar 66,97\%, sehingga perlu dilakukan penigkatan kembali suapaya pemlbelajaran dapat brjalan lebih efektif agar dapat meningkatkan kualitas pembelajaran dan hasil belajar siswa.

Selain beberapa contoh penelitian terdahulu diatas masih banyak lagi penelitian-penelitian llain yang juga membahas tentang dampak dan keefektifan dari diberlakukannya pembelajaran daring ini. Oleh karena itu penulis menganggap pentingnya dilakukan penelusuran tentang efektifitas serta dampak dilakukannya pembelajaran secara daring yang disebabkan adanya pandemic Covid-19 sekarang ini.

\section{METODE}

Menurut Sugiyono (2010:2) metode penelitian adalah cara ilmiah yang dilakukan dengan tujuan medapatkan data untuk kegunaan dan tujuan tertentu. Saat melakukan penelitian ini perlu adanya metode atau langkeh langkah yang harus dilalui seorang peneliti saat akan memecahkan sebuah permasalahan guna mecapai tujuan yang ingin dicapai oleh peneliti.

Metode yang akan digunakan dalam penelitian ini adalah metode penelitian survei. Seperti yang dituliskan Alsa (2004:20) bahwa rancangan survey adalah prosedur penelitian dengan cara peneliti memberikan angket yang memiliki skala tertentu pada suatu sampel untuk mengungkapkan sikap, prikaku, karakreristik mauppun opini yang dimiliki oleh responden.

Penelitian dengan menggunakan survey ini dilakukan dengan mengkaji populasi dengan metode sampel yang guna mengetahui prilaku dan karakteristik dari responden juga untuk menggeneralisasikan dan mendeskripsikan populasi yang sedang diteliti. Pada penelitian ini sampel yang digunakan adalah guru yang 
mengajar di sekolah dasar yang dipilih secara acak di kecamatan Bawang, Kabupaten Banjarnegara.

Dengan angket likert sebagai angket skala percobaan. Menurut Syofian (2015:3) dalam jurnal yang ditulisnya mengatakan bahwa skala likert adalah sebuah skala yang berkaitan dengan persetujuan atau pertentangan terhadap suatu hal. Terdapat dua kemungkinan dalam skala ini, pertama, berbentuk data ordinal (berjenjang tanpa skor), terdapat angka-angka namun hanya sebagai urutan saja. Sehingga, analisisnya hanya berbentuk frekuensi (banyaknya) atau bisa juga proporsinya(presentase). Yang kedua yaitu dengan menggunakan analisis terbanyak atau mode.

\section{HASIL}

Pada penelitian ini lebih memfokuskan tentang dan mapak dan efektifitas pembelajaran dari yang dirasakan oleh pengajar, karena sebagaimana kita ketahui selain siswa pengajar adalah salah satu pihak yang paling terdampak dengan adanya sekolah full daring ini, ada 20 responden yang merupakan pengajar di tingkat sekolah dasar yang ada di Kecamatan Bawang, Kabupaten Banjarnegara, Jawa tengah.

Aspek yang dikaji dalam penelitian ini adalah aspek dampak diberlakukannya sekolah daring serta keefektifan diberlakukannya sekolah daring, dari aspek dampak sekolah daring dipecah menjadi 11 indikator yang lebih spesifik tentang dampak dampak apa saja yang dirasakan oleh pengajar dan dari aspek keefektifan dipecah menjadi empat indikator.

Berikut adalah masing mesing presentase yang diperoleh dari responden mengenai dampak diberlakukannya sekolah daring dari setiap indikator yang diajukan didalam form. Yang pertama yaitu tentang apakah pengajar kesulitan menetukan metode pembelajaran yang cocok diterapkan selama diberlakukannya sekolah daring 75\% responden setuju dengen pernyataan ini. Lalu berikutnya adalah tentang Pengajar kesulitan menetukan media pembelajaran yang sesuai dengan sistem daring 55\% pengajar setuju responden menyetujui hal ini. Namun $45 \%$ responden lainnya tidak merasa mengalami kesulitan dalam mementukan metode pembelajaran yang sesuai untuk diberlakukan di kelas daring.

Berdasarkan hasil survei juga diketahui bahwa sering terjadi miskomunikasi baik antara pengajar dengan siswa maupun pengajar dengan wali murid dimana 80\% responden menjawab jika mereka sering mengalami miss komunikasi dengan siswa dan 65\% mengatakan jika mereka sering mengalami miss komunikasi dengan wali siswa semestara siswanya merasa jika tidak mengalami miss komunikasi selama diberlakukannya pembelajaran full daring.

Sarana prasana pendukung sangat diperlukan dalam memperlancar berjalannya sekolah daring, namun terkadang terdapat beberapa kendala dalam 
pengadaan sarana perndukung pelaksanaan diberlakukannya sekolah daring, berdasarkan hasil survey yang telah dilakukan 75\% pengajar mengalami kesulitan dalam pengadaan sarana pendukung sekolah daring. Selain itu, 60\% pengajar mengatakan sulitnya membenguun komunikasi dua arah natara siswa dengan pengajar selama diberlakukannya sekolah daring, dan 75\% responden mengungkapkan jika jika terdadat kesulitan menyampaikan materi kepada siswa selama diberlakukannya sekolah daring.

Berdasarkan hasil survei, 75\% responden mengungkapkan jika kecepat pemahaman siswa saat diberlakukannya sekolah daring lebih lambat jika dibandingkan dengan kecepatan pemahaman siswa saat diberlakukannya sekolah konvemsional atau sekolah off line. Selain itu, kendala yang paling sering dirasakan selama proses pembelajaran daring adalah adanya kendala koneksi internet saat berlangsungnya pembelajaran hal ini didukung juga dengan data hasil survei dimana 95\% responden setuju jika sering terjadi kendala selama pembelajaran daring dikarenakan koneksi internet.

Diberlakukannya sekolah daring juga membuat pengajar harus memangkas atau mengurangi beberapa sub materi pembelajaran, berdasarkan survey ada $90 \%$ responden yang mengungkapkan hal ini, 75\% responden menjawab jika selama diberlakukannya pembelajaran daring terjadi penurunan keaktifan siswa. Selain itu, dari segi keefektifan terdapat empat indikator untuk mengukur tingkat keefektifan sekolah daring dimasa pandemic ini, dari hasil survey didapat data seperti yang terdapat pada tabel 1. dibawah ini.

\section{Tabel 1}

Data hasil survei untuk mengukur keefektifan pembelajaran daring

\begin{tabular}{|c|c|c|c|c|c|}
\hline INDIKATOR & SS (\%) & S (\%) & KS (\%) & TS (\%) & STS (\%) \\
\hline $\begin{array}{l}\text { Pembelajaran secara daring lebih } \\
\text { efektif dibandingkan secara tatap } \\
\text { muka. }\end{array}$ & 5 & 0 & 35 & 35 & 25 \\
\hline $\begin{array}{l}\text { selama diberlakukannya sekolah } \\
\text { daring semua materi pelajaran } \\
\text { tetap dapat tersampaikan dengan } \\
\text { baik pada siswa. }\end{array}$ & 0 & 15 & 50 & 25 & 10 \\
\hline $\begin{array}{l}\text { Nilai siswa meningkat setelah } \\
\text { diberlakukannya sekolah daring. }\end{array}$ & 0 & 20 & 5 & 70 & 5 \\
\hline $\begin{array}{l}\text { Siswa samakin termotifasi untuk } \\
\text { belajar dengan diadakannya } \\
\text { sekolah daring. }\end{array}$ & 0 & 5 & 50 & 40 & 5 \\
\hline
\end{tabular}


Dimana :

SS $=$ Sangat setuju

$\mathrm{S}=$ Setuju

KS $\quad=$ Kurang setuju

TS $\quad=$ Tidak Setuju

STS = Sangat tidak setuju

Dari hasil analisis data hasil survey diperoleh jika keefektifan pembelajaran daring hanya sebesar 39,6\% hal ini tentu masih sangat rendah, sehingga perlu untuk ditingkatkan lagi hal ini sesuai dengan penelitian sebelumnya yang tulis oleh hamdani (2020) yang mengungkapkan bahwa tingkat efektifitas pembelajaran sekitar 66,97 \%, hal ini perlu ditingkatkan kembali agar pembelajaran lebih efektif guna peningkatan kualitas pembelajaran dan hasil belajar siswa.

\section{PEMBAHASAN}

Metode pembelajaran merupakan sesuatu yang sangat penting untuk mendukung berlangsungnya proses belajar mengajar yang baik. Namun menentukan metode pembelajaran yang sesuai untuk di aplikasikan dalam proses pembelajaran bukanlah sesuatu yang mudah, terlebih lagi untuk menentukan metode pembelajaran yang tepat untuk diterapkan di masa pandemi seperti saat ini.

Kesulitan menentukan media pembelajaran yang tepat digunakan di sama pandemi Covid-19 di karenakan saat pembelajaran daring, media yang digunakan sangat jauh berbeda dengan media yang digunakan saat pembelajaran tatap muka. Pada pembelajaranb tatap muka, pengajar sekolah dasar telah terbiasa menggunakan media papan tulis maupun ceramah didepan kelas saat menyampaikan suatu materi kepada siswa namun saat diberlakukannya pembelajaran full daring tentu saja media pembelajaran langsung berubah dari yang sebelumnya lebih konvensional beralih ke media digital yang belum biasa digunakan oleh pendidik (Batubara, 2020).

Hal ini juga dikemukakan oleh Mansyur (2020) dimana ia mengatakan jika saat pembelajaran daring, media pembelajaran bertransformasi lebih canggih, seperti video digital dan learning management system. Baik pengajar maupun siswa harus menggunakan media pembelajaran yang baru dengan suasanya yang tentunya baru juga. Miss komunikasi baik anatar pengajar dengan siswa maupun pengajar dengan wali siswa seringg terjadi selama pembelajaran daring hal ini dikarenalan saat pembelajaran daring komunikasi hanya bergantung pada alat komunikasi elektronik. 
Kesulitan pengadaan sarana prasarana penunjang kegiatan sekolah dating terjadi karena sekolah daring memerlukan perangkat-perangkat pendukung seperti smartphone maupun leptop namun tidak semua peserta didik memiliki perangkat ini sehingga tentu saja menjadi kendala bagi perlangsungnya proses pembelajaran daring. Dlam jurnalnya hamdani(2020) juga mengungkapkan jika pembelajaran yang diberlakukan secara daring membutuhkan perangkat seperti smart phone atau computer yang erkoneksi dengan internet. Namun terkadang kebutuham nimimal computer belum terpenuhi oleh siswa maupun uleh pengajar, hal in tentu saja akan berdampak pada berlangsungnya proses pembelajaran.

Dampak lain yang disebabkan karena berlakunya sekolah daring adalah sering terjadi kendala dalam proses pembelajaran dikarenakan koneksi internet, kita tahu jika saat pembelajaran dilakukan secara daring tentunya koneksi internet merupakan sesuatu yang sangat penting, jika tidak ada internet maka otomatis baik siswa maupun pengajar tidak dapat mengikuti pembelajaran. Dalam jurnalnya Mansyur (2020) juga mengungkapkan jika kelemahan diberlakukannya sekolah daring adalah daya dukung internet yang sering terganggu sehingga pembelajaran yang menggunakan media seperti tatap muka virtual tidak akan berjalan dengan maksimal.

Kesulitan membengun komunikasi dua arah biasanya terjadi pada saat pembelajaran dilakukan dengan menggunakan media Google Classroom dikarenakan siswa cenderung akan bersikap pasif saat pembelajaran, selain itu pemberian tugas atau materi dalam bentuk Microsoft Word juga akan membuat komunikasi dua arah antara pengajar dengan siswa sulit dilakukan.

Kesulitan penyampaian materi kepada isiwa terjadi karena terkadang pengajar sudah menyiapkan materi dalam bentuk Power Point atau dengan penjelasan secara langsung namun dikarenakan koneksi internet yang sering mengalami kendala proses penyampaian materi ini menjadi terkendala, terlebih lagi jika kendala sinyal dialami oleh siswa, pengajar tidak dapat mengetahui satu persatu siapa-siapa saja yang mengalami kesulitan koneksi dan belum menerima materi pembelajaran seperti yang seharusnya.

Sistem daring menghambat pemahaman siswa terhadap suatu meteri dikarenakan saat daring pengajar tidak dapat memeriksa tingkat pemahaman siswa per individunya, keterbatasan yang disebabkan oleh jarak menyebabkan antara siswa dengan siswa, maupun antara siswa dengan pengajar tidak dapat saling berkomunikasi secara bebas selama pembelajaran berlangsung, sementara komunikasi anatara siswa dengan pengajar sangatlah penting dalam sebuah kegiatan pembelajaran untuk mengetahui apakah semua siswa sudah memahami materi yang diajarkan atau belum, seperti yang dikatakan dalam penelitian sebelumnya yang dilakukan oleh Isnaini (2020) dalam jurnalnya dimana jika saat 
siswa tidak saling berkomunikasi secara langsung tingkat pemahaman siswa yang berbeda beda akan menjadi sebuah masalah.

Pengurangan atau pemangkasan sub materi terjadi untuk mempersingkat waktu pembelajaran sekolah daring, dikarenakan beberapa materi yang memerlukan percobaan akan sulit diimplementasikan dalam pembelajaran daring pada tinggat sekolah dasar sehingga harus dipangkas untuk mengoptimalkan dalam penyampaian materi lain yang dirasa lebih memungkinkan.

Pada sistem pembelajaran daring motivasi siswa sangatlah berpengaruh terhadap keaktifan siswa. Menurut Shadiqien (2020), motivasi merupakan dorongan berupa keinginan kuat dari dalam diri untuk melakukan suatu hal yang memiliki tujuan tertentu sebagai pemicu dan alasan melakukan sesuaatu. Siswa yang memiliki motivasi belajar yang tinggi cenderun akan sangat aktif dalam mengikuti pembelajaran daring namun siswa yang memiliki motivasi pembelajaran yang relative rendah cenderung lebih suka menjadi pengamat selama proses pembelajaran berlangsung sehingga tentu saja hal ini akan mempengaruhi tingkat keaktifan siswa didalam kelas daring. Terjadinya penurunan keaktifan disebabkan media dan metode pembelajaran yang belum dapat menarik motifasi siswa untuk mengukuti pembelajaran.

Pembelajaran yang efektif menurut Shadiqien (2020) adalah pembelajaran yang memberi ruang pada peserta didik untuk belajar secara baik dari segi keterampilan, pengetahuan, maupun sikap, sehingga secara efektif pembelajarn itu akan memberikan manfaat pada siswa dalam menumbuhkan kemampuan keterampilan, nilai konsep, dan menciptakan keserasian dengan sesama murid dari hasil belajar yang didapat. Rendahnya keefektifan pembelajaran daring dikarenakan siswa yang yang cenderung cepat merasa bosan saat mengikuti pembelajaran daring sehingga saat pembelajaran sudah mendekati akhir siswa cenderung tidak dapat menangkap apa yang sedang dijelaskan oleh pengajar, sehingga hal ini tentu membuat keefektifan sekolah daring akan berkurang,

Selain itu, rendahnya keefektifan pembelajaran daring juga dikarenakan media pembelajaran yang digunakan kurang menarik minat siswa untuk mengikuti pembelajaran daring hal ini sesuai dengan jurnal yang ditulis oleh Anugraha (2020) dimana dia mengatakan bahwa saat pembelajaran daring apalagi pada materi yang diberikan hanya dalam bentuk Microsoft Word siswa akan merasa bosan saat mengikuti pembelajaran daring. Namun saat media pembelajaran diganti dalam bentuk video siswa menjadi lebih aktif dan semangat dalam mengikuti pembelajaran daring.

Namun diluar itu, semua pembelajaran daring dapat menghemat waktu dan tentunya mencegah penyebaran Covid-19,. Dalam hal ini, pembelejaran daring tersedia fasilitas emoderating sehingga pengajar dengan siswa dapat berkomunikasi secara mudah melalui fasilitas internet secara reguler tanpa 
mengenal waktu tanpa dibatasi oleh waktu, jarak, maupun tempat (Suhery, 2020; Dewi, W. A. F., 2020).

\section{SIMPULAN}

Diberlakukannya sekolah daring dimasa pandemic Covid-19 pada jenjang pendidikan sekolah dasar di Kecamatan Bawang, Kabupaten Banjarnegara diantaranya adalah bahwa pengajar kesulitan dalam menetukan metode dan media yang akan digunakan dalam pembelaran daring, terjadi mis komunikasi antara pengajar dengan siswa dan pengajar dengan wali siswa selama diberlakukannya sekolah daring, adanya kesulitan dalam pengadaan sarana prasarana pendukung pelaksanaan kegiatan sekolah daring, sulit membangun komunikasi dua arah selama diberlakukannya sistem sekolah daring, selama diberlakukannya sekolah daring terdapat kesulitan untuk penyampaian materi kepada siswa, sistem sekolah daring menghambat pemahaman siswa terhadap suatu sering terjadi kendala sinyal selama berlakunya sistem sekolah daring.

Keefektifan pembelajaran daring dimasa pandemic Covid-19 di Kecamatan Bawang, Kabupaten Banjernegara baru mencapai 39,6\% sehingga perlu dilakukan evaluasi untuk agar tingkat keefektivan dapat meningkat dan pembelajaran bisa berjalan dengan lebih baik, serta tujuan dari diadakanya proses pembelajaran bisa terwujud.

\section{UCAPAN TERIMA KASIH}

Pertama-tama penulis ucapkan terimakasih sebesar-besarnya kepada Allah SWT yang sudah memberikan nikmat sehat dan nikmat sempat sehingga artikel ini dapat deselesaikan dengan tepat waktu, selain itu terimakasih juga penulis ucapkan kepada Prof. Dr. Ani Rusilowati, M. Pd. dan Fianti, S. Si., M. Sc., Ph. D. yang telah memberikan bimbingan kepada penulis sehingga artikel ini dapat diselesaikan dengan baik.

\section{DAFTAR PUSTAKA}

Alsa, Asmadi. (2004). Pendekatan Kualitatif dan Kuantitatif serta Kombinasinya dalam penelitian Psikologi. Yogjakarta: Pustaka Pelajar.

Andri, AnugrahanaAndri. (2020). Hambatan, Solusi dan Harapan: Pembelajaran Daring Selama Masa Pandemi Covid-19 Oleh Guru Sekolah Dasar. Scholaria: Jurnal Pendidikan dan Kebudayaan,10(3),283.

Batubara, H. H., \& Batubara, D. S. (2020). Penggunaan Video Tutorial Untuk Mendukung Pembelajaran Daring Di Masa Pandemi Virus Corona. Muallimuna: Jurnal Madrasah Ibtidaiyah, 5(2), 74-84. 
Dewi, W. A. F. (2020). Dampak Covid-19 terhadap implementasi pembelajaran daring di Sekolah Dasar. Edukatif: Jurnal Ilmu Pendidikan, 2(1), 55-61.

Hamdani, Acep Roni, \& Priatna, Asep. (2020) . Efektifitas Implementasi Pembelajaran Daring (Full Online) Dimasa Pandemi Covid- 19 Pada Jenjang Sekolah Dasar Di Kabupaten Subang. Didaktik : Jurnal Ilmiah PGSD STKIP Subang. 6(1). 6-9.

Hamdarini, Oktafia Ika . (2020). Pembelajaran Daring Sebagai Upaya Study From Home (SFH) Selama Pandemi Covid 19. Jurnal Pendidikan Administrasi Perkantoran (JPAP). 8(3) . 7.

Handarini, O. I., \& Wulandari, S. S. (2020). Pembelajaran Daring Sebagai Upaya Study From Home (SFH) Selama Pandemi Covid 19. Jurnal Pendidikan Administrasi Perkantoran (JPAP), 8(3), 496-503.

Isnayni, Mila Yatimatul, \& Hermansyah wildan. (2020). Pengaruh Pembelajaran Sistem Daring Terhadap Mahasiswa Tadris Biologi Dalam Memahami Materi Mata Kuliah Biokimia. Alveoli: Jurnal Pendidikan Biologi. 1(1).5.

Mansyur, Abd. Rahim. (2020). Dampak COVID-19 Terhadap Dinamika Pembelajaran Di Indonesia. Education and Learning Journal. 1(2). 7.

Oktavian, R., \& Aldya, R. F. (2020). Efektivitas Pembelajaran Daring Terintegrasi di Era Pendidikan 4.0. Didaktis: Jurnal Pendidikan dan Ilmu Pengetahuan, 20(2).

Shadiqien, Shen. (2020). Efektivitas Komunikasi Virtual Pembelajaran Daring Dalam Masa Psbb (Studi Kasus Pembelajaran Jarak Jauh Produktif Siswa Smk Negeri 2 Banjarmasin). Mutakallimin; Jurnal Ilmu Komunikasi. 3(1).4.

Sugiyono. 2010. Metode Penelitian Pendidikan Pendekatan Kuantitatif, kualitatif, dan $R \& D$. Bandung: Alfabeta.

Suhery, Putra, Trimardi Jaya, \& Jasmalinda. (2020). Sosialisasi Penggunaan Aplikasi Zoom Meeting Dan Google Classroom Pada Guru Di Sdn 17 Mata Air Padang Selatan. Jurnal Inovasi Penelitian. 1(3). 2.

Syofian, Suzuki, Setiyaningsih, Timor, \& Syamsiah, Nur. (2015). Otomatisasi metode penelitian skala likert berbasis Web. Seminar Nasional Sains dan Teknologi 2015 Fakultas Teknik Universitas Muhammadiyah Jakarta . 3.

Wiyanto. (2020). Proses Pembelajaran Matematika Di Sekolah Dasar Di Tengah Pandemi Covid-19. Jurnal Review Pendidikan Dasar: Jurnal Kajian Pendidikan dan Hasil Penelitian. 6(2). 3. 